\title{
Pengelolaan Komunikasi Pekerja Anak di Industri Kecil Boneka Kain Kopo Bandung
}

\author{
IKE J UNITA TRIWARDHANI ${ }^{1}$, WULAN TRIGARTANTI ${ }^{2}$ \\ 1,2 Fakultas IImu Komunikasi, Universitas Islam Bandung, JI. Tamansari No.1 Bandung \\ email: 1junitatriwardhani@yahoo.com,22 gartanti@yahoo.com
}

\begin{abstract}
Child workers are still found as informal employees in small or household industries. Working consequences tend them do not well-protected their safety, because they have different anatomy with adult. But, the necessity to support their family economically cause them live in highly risk working. Communication obstacles are also found when they interact with their uplines or other adults. It is impacted that child workers become usual to communicate as like as adult, and it effects the problems in their children communication development.
\end{abstract}

Keyword: Child workers, small industries, interaction, communication obstacles

\begin{abstract}
Abstrak. Pekerja anak masih ditemui sebagai pekerja informal di industri kecil atau rumah tangga. Konsekuensi pekerjaan menjadikan pekerja anak cenderung tidak terlindungi keselamatannya karena perbedaan anatomi yang berbeda dengan orang dewasa. Namun tuntutan untuk menghidupi keluarga menjadikan pekerja anak hidup dalam pekerjaan yang penuh risiko. Hambatan dalam komunikasi juga mereka temui saat berinteraksi dengan atasan atau rekan dewasa lainnya. Akibatnya, pekerja anak terbiasa berkomunikasi selayaknya orang dewasa, dan ini menjadikan permasalahan dalam perkembangan komunikasinya sebagai anak-anak.
\end{abstract}

Kata Kunci: Pekerja anak, industry kecil, interaksi, hambatan komunikasi

\section{Pendahuluan}

Pekerja anak dibawah umur banyak kita temui di berbagai perkotaan di Indonesia. Data Sakernas tahun 2003 menunjukkan jumlah pekerja anak-anak (dibawah usia 15 tahun) mencapai 556.526 anak. Mayoritas dari mereka menjadi pekerja di sektor informal seperti pada bidang pertanian atau pada industri-industri rumahan.

J awa Barat juga merupakan daerah dengan kasus-kasus pekerja anak yang terbilang banyak. Berdasarkan hasil penelitian Borualogo dalam Mimbar J urnal Sosial dan Pembangunan, tentang Pekerja Anak di Desa Cisolok Sukabumi, menyatakan bahwa propinsi Jawa Barat merupakan salah satu propinsi di Indonesia dengan jumlah penduduk yang sangat besar dan memiliki beragam permasalahan yang berkaitan dengan kondisi sosial budaya, termasuk kasuskasus pekerja usia anak (Baruologo, 2008: 178).

Selain di Desa Cisolok Sukabumi, di daerah Kabupaten Bandung juga banyak di temui permasalahan pekerja anak. Salah satunya adalah di industri boneka kain di daerah Kopo Kabupaten Bandung. Disini kita dapat temui anak-anak yang secara usia tidak sepantasnya bekerja tapi mereka justru menghabiskan waktunya untuk bekerja. Pekerja anak mudah terpapar sejumlah bahaya bagi keselamatan dan kesehatan. Anakanak memiliki karakteristik anatomi, fisik, dan psikologis yang berbeda dengan orang dewasa. Dapat kita bayangkan dengan usia sedini ini, anakanak tersebut tidak dapat menikmati masa kecil mereka dengan sewajamya seperti halnya anakanak yang lain. Dengan tuntutan kebutuhan keluarga mereka harus mengorbankan keselamatan, kesehatan, kesejahteraan bahkan dunia mereka.

Dalam kesehariannya bekerja dimana anak berkumpul dengan pekerja dewasa, maka lingkungan yang dihadapinya sehari-hari akan sangat berbeda dengan lingkungan normalnya. Anak akan cenderung meniru apa yang dilakukan dan ditampilkan oleh orang lain dilingkungannya untuk mencapai tujuan mereka dan dari sinilah panduan sistem nilai akan terbentuk (Boroualogo, 2008: 178). Selain itu, Sebagai pekerja anak, ia akan berhadapan dengan atasan, dalam hal ini pemilik usaha, atau pun pekerja lain yang lebih dewasa, sehingga dalam berkomunikasi mereka banyak menemukan hambatan, maka mereka 
dituntut untuk mampu mengelola komunikasi dengan lingkungan kerja yang tidak bersahabat, sehingga pekerja anak tidak diperlakukan semenamena oleh orang dewasa di lingkungan kerjanya. Dari fenomena pekerja anak diatas, maka sangat penting melihat bagaimana pekerja anak mengelola komunikasi dengan orang dewasa di lingkungan kerjanya.

Tulisan ini merupakan hasil penelitian pada industri boneka kain di kabupaten Bandung. Dari hasil penellitian tersebut kami mencoba menggambarkan, sebagai berikut: (1) konstruksi realitas pekerja anak dilihat dari kondisi sosial ekonomi dan kondisi psikologis; (2) Dampak industri boneka kain bagi pekerja anak; (3) pengelolaan komunikasi pekerja anak di lingkungan kerja.

\section{Konstruksi Realitas Pekerja Anak}

Fenomena pekerja anak mulai berkembang di Indonesia sejak krisis ekonomi tahun 1997. Karena kebutuhan ekonomi yang semakin mendesak, banyak orang tua yang tidak mampu memenuhi kebutuhan hidup keluarganya, membiayai sekolah anak-anaknya, sehingga banyak anak-anak yang putus sekolah dan akhirnya bekerja untuk membantu memenuhi kebutuhan keluarga.

Pemerintah Indonesia mulai menangani masalah pekerja anak secara lebih serius setelah krisis ekonomi tahun 1997. Pada tahun 1990, Indonesia meratifikasi Konvensi PBB tentang Hak Anak-anak, melalui Keputusan Presiden Republik Indonesia No. 36/1990.

Melalui Undang-undang No. 20/1999 dan 1/ 2000, pemerintah telah meratifikasi Konvensi ILO No. 38 tentang umur minimum seseorang untuk bekerja dan Konvensi ILO No. 182 tentang penghapusan dan tindakan segera untuk menghapuskan pekerjaan terburuk bagi anak-anak

Melalui Keputusan Presiden (Keppres) No. 59/2002 baru-baru ini, Pemerintah mengidentifikasi 13 jenis pekerjaan terburuk untuk anak yang harus segera diatasi dalam Program Terikat Waktu. Jenis-jenis pekerjaan yang dilarang tersebut adalah anak-anak yang dilacurkan, anakanak yang bekerja di pertambangan, sebagai penyelam mutiara, di sektor konstruksi, sebagai pemulung sampah, di kegiatan-kegiatan yang menggunakan bahan peledak, di jalan, sebagai pembantu rumah tangga, di industri rumah tangga, di perkebunan, di penebangan, pengolahan dan pengangkutan kayu dan di kegiatan-kegiatan yang melibatkan pemakaian bahan kimia berbahaya.

Walaupun undang-undang tersebut secara jelas melarang pekerja anak yang berusia 18 tahun atau kurang di semua sektor ekonomi, namun kebutuhan ekonomi dan kurangnya alternatif, seperti sekolah, memaksa atau mendorong anakanak bekerja.

\section{Pekerja Anak di I ndustri Boneka Kain}

Sentra Industri boneka kain yang terletak di daerah Kopo Sayati Kabupaten Bandung mulai dirintis sekitar tahun 80an dan berkembang pada sekitar tahun 90an. Letak daerahnya yang strategis membuat industri boneka ini berkembang dan mampu bertahan hingga sekarang.

Lokasinya dikatakan strategis karena merupakan daerah yang ramai dan mudah diakses oleh transportasi. Daerah ini merupakan jalur utama yang dilalui oleh angkutan kota arah bandung-soreang. Daerah ini juga merupakan jalur utama kendaraan menuju daerah wisata bandung selatan (Ciwidey), sehingga hasil industri boneka ini juga menjadi buruan para wisatawan yang melancong ke daerah bandung selatan untuk dijadikan oleh-oleh.

Di sentra industri boneka kain yang ada di jalan Kopo Sayati, yang merupakan lokasi dalam penelitian ini juga terdapat sejumlah pekerja anak, yang termasuk ke dalam kategori ketiga, yaitu yang berusia 15-17 tahun dengan jam kerja 40 jam seminggu.

Selain itu, menurut pemerintah Indonesia, merujuk kepada UU Nomor 20 Tahun 1999 tentang Ratifikasi Konvensi ILO 138, dinyatakan bahwa usia minimum diperbolehkan bekerja untuk pekerjaanpekerjaan yang membahayakan kesehatan, keselamatan atau moral anak harus diupayakan tidak boleh kurang dari 18 tahun.

Pekerja anak pada industri boneka kain ini biasanya diberi tugas yang ringan yaitu pengisian Dakron ke dalam boneka dan pemotongan sisasisa benang untuk merapikan jahitan. Sepertinya pekerjaan ini memang mudah. Tetapi apabila kita telaah lebih lanjut dengan memperhatikan kondisi tempat pembuatan boneka kain maka pekerjaan mereka bukan tanpa resiko.

Tempat proses produksi boneka kain atau yang mereka sebut gudang merupakan ruangan tertutup yang meski penerangan cukup tetapi nampaknya sirkulasi udara kurang memadai. Ruangan tersebut bertambah pengap dengan banyaknya stok bahan-bahan seperti kain, bahan dakron dan bahan pelengkap lainnya. Kondisi tempat bekerja seperti diuraikan diatas tentu saja kurang baik bagi kesehatan.

Tugas pekerja anak mengisi dakron ke dalam boneka dilakukan tanpa menggunakan masker pelindung, sementara bahan dakron sangat berpotensi mengeluarkan debu, kondisi ini tentu saja semakin membuat pekerja anak rentan terhadap penyakit, terutama penyakit pernafasan. Belum lagi seringkali mereka melakukan pekerjaannya bertelanjang dada, hanya 
menggunakan celana pendek saja. Pekerja anak pada industri boneka kain kopo sayati memiliki jam kerja yang sama dengan pekerja dewasa. Hal ini tentu saja kurang cocok dengan kondisi fisik anak, karena kekuatan fisik anak-anak berbeda dengan orang dewasa, bahkan anak-anak membutuhkan waktu istirahat yang lebih banyak dibanding orang dewasa.

\section{Kondisi Sosial Ekonomi Pekerja Anak di I ndustri Boneka Kain Kopo Sayati}

Pekerja anak yang bekerja di sentra industri boneka kopo sayati sebenarnya bukan berasal dari daerah setempat, melainkan kebanyakan berasal dari daerah Cianjur, Tasik, Ciparay, Sumedang dan daerah lainnya. Lemahnya ekonomi keluarga, sementara tuntutan biaya hidup semakin tinggi, menjadi faktor pendorong anak-anak bekerja untuk menambah penghasilan keluarga.

Lemahnya ekonomi keluarga juga menyebabkan anak-anak ini tidak dapat melanjutkan pendidikannya. Sehingga kebanyakan anak-anak yang bekerja pada industry boneka kain kopo sayati ini merupakan anak-anak putus sekolah. Mereka hanya mengenyam pendidikan sampai jenjang sekolah dasar saja, bahkan beberapa diantaranya tidak sampai menyelesaikan pendidikan sekolah dasar.

Orangtua para pekerja anak di daerah Kopo Sayati ini rata-rata bekerja sebagai buruh tani, penghasilan orangtua yang rendah dan tidak menentu tidak cukup untuk memenuhi kebutuhan sehari-hari. Tingginya biaya pendidikan juga menyebabkan anak-anak ini putus sekolah, jangankan untuk biaya pendidikan, untuk biaya kebutuhan sehari-hari saja tidak mencukupi.

Meningkatnya angka kemiskinan terlebih lagi semenjak krisis memang menjadi faktor yang berpengaruh besar terhadap maraknya pekerja anak di Indonesia. Dampak dari krisis ini adalah anjloknya penghasilan serta meningkatnya angka pengangguran orang dewasa. Tuntutan biaya hidup, biaya pendidikan anak, dan biaya lain-lain yang semakin besar menyebabkan anak-anak terpaksa putus sekolah dan bekerja untuk membantu orangtua memenuhi kebutuhan hidup. Akibatnya, jumlah anak yang ingin membantu kelangsungan hidup keluarga mereka pun meningkat, demikian pula halnya anak yang kehilangan kesempatan untuk menikmati hak mereka untuk mengenyam pendidikan dan menikmati masa kanak-kanak mereka.

Salah satu strategi untuk mengatasi masalah ekonomi keluarga adalah pemanfaatan sumber daya manusia (anggota keluarga yang ada). Pandangan ini mengisyaratkan, bahwa anak merupakan salah satu aset untuk mengatasi masalah ekonomi keluarga. Akibatnya tidak ada lagi pilihan bagi anak, mereka harus bekerja untuk menambah penghasilan keluarga.

Menurut pengakuan beberapa pekerja anak yang bekerja di industri boneka sayati ini memang setiap bulannya mereka mengirimkan uang hasil mereka bekerja kepada orang tua mereka di kampung, ada juga beberapa anak yang mengumpulkan penghasilan mereka, dan secara rutin 3 atau 4 bulan sekali mereka meminta ijin pulang untuk menyerahkankan langsung uang yang terkumpul kepada orangtua mereka. Memang tidak seluruh penghasilan mereka serahkan kepada orangtua mereka, karena sebagian mereka gunakan untuk memenuhi kebutuhan mereka sehari-hari.

Dan menurut pengakuan pekerja anak itu sendiri juga orang tua mereka terpaksa merelakan anaknya pergi merantau untuk bekerja membantu ekonomi keluarga. Diperkirakan pekerja anak ratarata memberi sumbangan 20-25 persen bagi ekonomi keluarga. Dengan jumlah sebesar itu wajar jika banyak orangtua dengan ekonomi paspasan merelakan anaknya mencari tambahan penghasilan. Selain membantu menambah penghasilan keluarga, bila anaknya bekerja berarti mengurangi beban pengeluaran karena mereka dapat memenuhi sendiri kebutuhan hidupnya.

Adapun motivasi anak-anak sendiri untuk bekerja di sentra industri boneka kain ini berbedabeda. Sebagian dari mereka bekerja karena disuruh orangtua, beberapa dari mereka bekerja karena memang ingin membantu ekonomi orangtua mereka. Sebagian lagi karena mereka tidak punya pilihan lain selain bekerja untuk mengisi waktu mereka karena akses mereka ke pendidikan sudah tertutup, Mereka sudah putus sekolah sehingga ketika ada teman atau kerabat yang mengajak bekerja mereka dengan mudah menerima ajakan itu.

Pekerja anak yang bekerja di sentra industri boneka kain kopo sayati ini pada awalnya tidak memiliki modal keterampilan sama sekali, mereka pergi keluar daerah dan bekerja di sentra industri boneka kain kebanyakan karena dibawa oleh teman atau kerabatnya yang sudah terlebih dahulu bekerja di sentra industri ini.

Para pengrajin sendiri juga tidak keberatan menerima mereka meski tanpa berbekal keterampilan sama sekali. Dengan beberapa alasan diantaranya yaitu karena mereka berniat membantu, kemudian juga karena tugas pekerjaan yang diberikan mudah dan bisa diajarkan dalam waktu singkat.

Memang tugas pekerjaan yang diberikan kepada pekerja anak di sentra industri boneka kain ini relatif ringan dan tidak membutuhkan keterampilan. Untuk pekerja yang baru biasanya diberi tugas yang paling ringan yaitu mengisi bahan dakron ke dalam boneka yang sudah dijahit 
dan kemudian menggunting sisa-sisa benang untuk merapikan jahitan. Salah satu alasan lain pengrajin mempekerjakan pekerja anak yang tidak bermodal keterampilan sama sekali adalah upah yang rendah. Anak-anak yang datang untuk bekerja pada industri ini tidak memiliki posisi tawar, mereka menerima begitu saja, berapapun upah yang diberikan pengusaha kepada mereka. Upah yang diberikan berbeda-beda sesuai dengan jenis pekerjaan. Pekerjaan pengisian dan menggunting yang dianggap pekerjaan paling ringan upahnya lebih rendah dibanding pekerjaan menggambar pola dan menjahit. Pekerjaan pengisian dan menggunting notabene dikerjakan oleh pekerja anak, sedangkan pekerjaan menjahit dan menggambar pola dilakukan oleh pekerja dewasa. Berarti upah pekerja anak lebih rendah dibandingkan upah pekerja dewasa.

\section{Kondisi Psikologis Pekerja Anak di I ndustri Boneka Kain Kopo Sayati}

Pekerja anak yang bekerja di sentra industri boneka kain kopo sayati bukan berasal dari daerah setempat. Seperti telah dijelaskan sebelumnya, mereka berasal dari daerah yang berbeda-beda, ada yang dari daerah Cianjur, Tasik, Ciparay, Sumedang dan daerah lainnya. Karena jauh dari tempat tinggalnya, maka semua pekerja pada sentra industri boneka tinggal dan menginap di gudang tempat proses produksi.

Mereka tinggal di tempat yang pengap, bersatu dengan stok bahan-bahan produksi, seperti kain, benang, dakron dll. Dalam tumpukan kain, benang, dakron tentu saja banyak terdapat debu yang dapat mengganggu kesehatan. Kondisi ini tentu saja kurang baik bagi proses tumbuh kembang anak. Lingkungan yang kurang sehat dapat menghambat proses pertumbuhan dan perkembangan anak, baik perkembangan fisik maupun psikologis. Pekerja anak tinggal di gudang tempat proses produksi bersatu dengan pekerja dewasa lainnya. 24 jam mereka bergaul dengan pekerja dewasa, dimana diantaranya ada juga pekerja dewasa yang sudah menikah, terkadang mereka terlibat pembicaraan orang dewasa.

Berdasarkan hasil pengamatan peneliti di lapangan ketika mendengarkan para pekerja terlibat pembicaraan, termasuk dengan pekerja anak. Nampak sekali pengaruh lingkungan terhadap pekerja anak. Dari bahasa yang digunakan oleh pekerja anak, kemudian dari perbendaharaan kata yang keluar dari mulut pekerja anak, kemudian dari isi pembicaraan pun sangat "tidak anak-anak".

Lingkungan pekerjaan tempat anak-anak bekerja nampaknya bukan lingkungan pendidikan atau media pembelajaran yang layak bagi mereka. Lingkungan pekerjaan anak menjadi lingkungan yang tidak representatif untuk menyokong proses pematangan intelektual anak. Lingkungan ini memendekkan proses pendewasaan diri anak dan membuat perkembangan jiwanya menjadi terhambat.

Di samping apa yang dikemukakan diatas, lingkungan pekerjaan anak juga membangun hubungan antara anak-anak dan para pekerja dewasa. Mereka berada dalam poros komunikasi yang timpang. Dari pihak orang dewasa, pekerja anak dipandang oleh mereka sebagai pihak yang inferior (lemah, mudah diatur, senantiasa patuh dan lain sebagainya). Dalam kacamata psikologi anak, orang dewasa dipandang mereka sebagai pihak yang sebaliknya. Orang dewasa diletakkan dalam posisi yang superior (kuat, suka memerintah, wajib dihormati, dapat dijadikan tempat mengadu, dan lain sebagainya).

Di tempat bekerja, terkadang anak-anak terserang penyakit, seperti pusing-pusing, panas dingin dll. Setelah diobati tidak sembuh-sembuh. Akhirnya dipulangkan dulu ke rumah orang orangtuanya dan langsung sembuh.

Kejadian tersebut menandakan adanya pengaruh secara psikologis bila anak berjauhan dari orangtua. Karena anak masih sangat membutuhkan orangtua, mereka membutuhkan kasih sayang dan perhatian, serta bimbingan orang tua. Pemilik usaha dan orang dewasa yang ada di lingkungan kerjanya tentu saja tidak dapat menggantikan peran orang tua tersebut.

\section{Dampak Industri Boneka Kain bagi Pekerja Anak}

Keberadaan pekerja anak di sentra industri boneka kain tentu saja menimbulkan berbagai dampak. Dampak kesehatan dan keselamatan terlihat pada pekerja anak memiliki daya tahan tubuh yang lebih lemah dibandingkan dengan pekerja dewasa, mereka sangat rentan terhadap penyakit, apalagi pada lingkungan kerja yang tidak memenuhi standar kesehatan. Tempat bekerja pengap dan sirkulasi udara kurang. Ditambah bertumpuknya stok bahan-bahan produksi seperti kain, benang, dakron, dan bahan-bahan aksesories lainnya, maka gangguan yang mungkin timbul pada pekerja anak antara lain kepanasan, mudah lelah, kepala pusing, pusing, meriang, batuk dll.

Selain itu, stok bahan baku yang bertumpuk ditambah limbah kain yang berserakan berpotensi menumpuknya debu, sehingga anak-anak juga rentan terhadap penyakit gangguan pernafasan. Belum lagi tugas mereka mengisi bahan dakron ke dalam boneka yang sudah dijahit dilakukan tanpa menggunakan masker penutup wajah sehingga dengan mudah debu pada dakron terhisap. J am kerja yang panjang, yaitu jam 7 pagi sampai jam 5 sore, kurang lebih 10 jam perhari, 
yang berarti lebih dari 40 jam perminggu, juga dapat berpengaruh pada kesehatan anak. Karena kekuatan fisik anak berbeda dengan orang dewasa, orang dewasa mungkin tahan bekerja berjam-jam, sedangkan anak-anak tidak, mereka membutuhkan waktu istirahat yang lebih lama.

Dalam jangka panjang kondisi ini dapat menghambat proses pertumbuhan. Ditambah lagi posisi kerja yang mengharuskan mereka duduk terus menerus, sementara anak membutuhkan gerak yang dinamis untuk melatih otot motorik nya agar mencapai pertumbuhan yang optimal.

Pekerja dewasa pada industri boneka kain biasanya menghisap rokok, dan pemilik tidak melarang pekerjanya merokok. Sudah difahami bersama bahwa rokok dan asapnya sangat berbahaya bagi kesehatan, Tidak hanya menjadi perokok pasif, bahkan banyak diantara pekerja anak yang terpengaruh dan akhirnya menjadi perokok juga. Hal sangat membahayakan kesehatan anak.

Resiko keselamatan yang mungkin muncul adalah terluka karena terkena gunting yang digunakan untuk bekerja. Tetapi tidak menutup kemungkinan mereka terluka karena mesin jahit, atau tertusuk jarum atau bahan yang lain karena penyimpanan bahan-bahan yang tersebar dimanamana. Namun pemilik usaha memberikan jaminan kesehatan bagi para pekerjanya. Pemilik akan memeriksakan ke Dokter apabila ada pekerjanya yang sakit. Semua biaya pengobatan pekerja akan ditanggung oleh pemilik.

Dampak lain yang juga muncul adalah dampak sosial dan psikologis. Pekerja anak yang bekerja pada sentra industri boneka kain kopo sayati semuanya putus sekolah, ada yang hanya sampai jenjang pendidikan dasar, ada juga yang sampai jenjang sekolah menengah (SMP). Hilangnya kesempatan anak-anak untuk megenyam pendidikan tentu saja berpengaruh terhadap kehidupan sosial dan perkembangan intelektualnya. Di sekolah anak-anak tidak hanya belajar berbagai ilmu pengetahuan, tetapi juga belajar bersosialisasi, belajar bagaimana berkehidupan sosial, memiliki teman-teman sebaya sehingga dapat tumbuh dan berkembang secara normal sesuai dengan pertumbuhan usianya.

Pergaulan pekerja anak dengan pekerja dewasa juga berdampak negatif terhadap kehidupan sosial anak. Mereka menjadi dewasa sebelum waktunya. Dalam percakapan sehari-hari anak-anak menggunakan bahasa yang digunakan orang dewasa, bahkan kerap anak-anak juga terlibat pembicaraan orang dewasa yang sama sekali tidak pantas dibicarakan oleh anak-anak karena sebagian pekerja dewasa telah menikah.

Dampak lain dari pergaulan dengan pekerja dewasa adalah terhadap pola hidup atau kebiasaan yang dapat membahayakan kesehatan fisik maupun psikis pekerja anak, seperti kebiasaan merokok yang dilakukan oleh pekerja dewasa. Sebagian pekerja anak yang bekerja di industri boneka juga melakukan kebiasaan merokok.

Hilangnya peran orangtua dalam membimbing dan mengarahkan anak karena mereka tinggal jauh dari orangtua, juga memberikan dampak yang kurang baik. Pekerja anak mudah terpengaruh oleh pekerja dewasa. Pekerja dewasa tidak berperan sebagai orang tua, justru mereka cenderung memberi pengaruh yang kurang baik, memperlakukan pekerja anak sebagai orang yang lemah sehingga sering menyuruh, melibatkan anak dalam pembicaraan yang seharusnya hanya diketahui oleh orang dewasa.

Dalam hubungan antara anak-anak dan para pekerja dewasa berlaku proses komunikasi yang timpang. Dari pihak orang dewasa, pekerja anak dipandang oleh mereka sebagai pihak yang inferior (lemah, mudah diatur, senantiasa patuh dan lain sebagainya). Dalam kacamata psikologi anak, orang dewasa dipandang mereka sebagai pihak yang sebaliknya. Orang dewasa diletakkan dalam posisi yang superior (kuat, suka memerintah, wajib dihormati, dapat dijadikan tempat mengadu, dan lain sebagainya).

Anak-anak masih sangat membutuhkan perlindungan, perhatian dan kasih sayang orang tua, jauhnya pekerja anak dengan orang tuanya secara tak sadar mempengaruhi kondisi psikologis anak yang terlihat pada kondisi kesehatan anak, terbukti ketika mereka sakit mereka baru sembuh ketika pulang dan bertemu orang tuanya untuk kemudian kembali lagi ke tempat kerjanya.

\section{Pengelolaan Komunikasi Pekerja Anak}

Pekerja yang masih berusia anak-anak cukup mendominasi sentra-sentra industri boneka di daerah Kopo Sayati. Dalam keseharian menjalankan pekerjaannya, mereka selalu berinteraksi baik dengan sesama pekerja anak, dengan pekerja dewasa dan dengan atasannya secara langsung.

Lingkungan kerja anak membentuk interaksi antara pekerja anak dengan atasan. Komunikasi yang yang terjadi sering bersifat satu arah dan lebih bersifat instruksi yang berkaitan dengan pekerjaan. Pekerja anak biasanya berusaha mengikuti instruksi yang diberikan kepadanya dan menyampaikan pertanyaan sebagai respon ketidakpahaman terhadap instruksi yang diberikan.

Dalam komunikasi antara pekerja anak dengan atasan, motivasi sering diperoleh anak, khususnya melalui komunikasi nonverbal yang disampaikan oleh pemilik yaitu melalui kerja keras, kesuksesan mengelola usaha, kemampuan secara ekonomi membuat anak merasa sangat hormat pada pemilik. Sehingga anak melihat pemilik 
sebagai figur tempat mereka bergantung secara ekonomi.

Supervisor yang memimpin pekerjaan dilapangan melakukan komunikasi dengan memberikan instruksi pekerjaan yang harus dilakukan anak. Pekerja anak-anak biasanya langsung menjalankan instruksi tersebut karena mereka sudah biasa melakukannya dan merupakan tugas mereka sehari-hari. Bila ada kesulitan, misalnya karena ada teknik baru yang berkaitan dengan bentuk boneka baru, atau tas dengan model pengisian yang lain, maka anak akan berkomunikasi dengan bertanya pada supervisor.

Hal-hal lain yang dikomunikasikan kepada supervisor adalah tentang penghasilan atau gaji yang mereka terima. Selain itu mereka juga mengkomunikasikan keinginan mereka misalnya ketika pamit untuk bermain atau berjalan jalan di luar lingkungan tempat kerja, bahkan ijin untuk menengok orang tua di kampung. Bila dibandingkan dengan pemilik industri, komunikasi dengan supervisor lebih intensif.

Selain berkomunikasi dengan atasan, dalam kesehariannya mengerjakan berbagai pekerjaan di industri boneka Kopo Sayati pekerja anak-anak selalu berdampingan dengan pekerja dewasa yang jumlahnya lebih banyak. Hal ini membuat komunikasi yang terjadi antara pekerja anak dan pekerja dewasa cukup intensif.

Interaksi yang terjadi dalam konteks pekerjaan yaitu ketika pekerja dewasa harus membimbing pekerjaan yang dilakukan oleh pekerja anak setiap harinya. Hal ini dilakukan terutama ketika ada pekerjaan yang baru yang harus dilakukan oleh pekerja anak.

Percakapan informal seringkali dilakukan antar mereka sambil melakukan pekerjaan masing-masing. Lelucon-lelucon yang lebih sering ditujukan untuk orang dewasa sering muncul dalam percakapan informal tersebut, dan bahkan anak yang seringkali menjadi sasaran lelucon. Sangat jarang terjadi percakapan yang sesuai dengan usia anak-anak. Namun karena kondisi ini membuat pekerja anak-anak juga mampu merespon pesan yang disampaikan oleh pekerja dewasa yang seringkali tidak cocok dengan usia anak-anak.

Sesama pekerja anak yang jumlahnya lebih kecil dibanding dengan pekerja dewasa, anak melakukan interaksi sehari-hari baik ketika bekerja maupun diluar pekerjaan. Hal ini karena mereka tinggal bersama-sama disebuah rumah yang disediakan oleh pemilik industri.

Dalam kesehariannya, ruangan tempat bekerja maupun tempat tinggal pekerja anak tidak dipisahkan dengan pekerja dewasa, sehingga mereka juga bergaul dan bersama-sama dengan pekerja dewasa. Walaupun begitu, pada waktuwaktu tertentu sesama pekerja anak terlihat melakukan komunikasi yang intensif terutama ketika bermain diluar waktu bekerja. Pekerja anak lebih banyak menghabiskan waktu bercengkerama saat beristirahat bersama pekerja anak, walaupun dengan pekerja dewasa juga mereka lakukan. Tema bincang-bincang yang lain disela-sela waktu bekerja biasanya berkaitan dengan hobby yang mereka suka, merancang tempat untuk berjalanjalan dan percakapan ringan lainnya.

\section{Prinsip-prinsip Komunikasi yang harus Dikembangkan}

Komunikasi efektif harus selalu diupayakan untuk mencapai hasil yang maksimal dalam sebuah kegiatan komunikasi. Untuk mencapai komunikasi yang efektif, maka harus dikembangkan prinsipprinsip komunikasi. Dari berbagai sumber dan penelitian pakar, penulis menyimpulkan ada beberapa prinsip komunikasi yang harus dikembangkan dalam berkomunikasi dengan anak.

Prinsip yang pertama adalah meningkatkan kredibilitas. Bagi orang dewasa apalagi bagi seseorang yang dihormati oleh seorang anak (apakah sebagai orang tua, atasan, maupun guru) mempunyai kredibilitas yang tinggi di mata anak, maka akan membuat anak lebih percaya dan dapat mengubah pendapat dengan ketertarikan langsung. Umumnya semakin tinggi kredibilitas seseorang akan memberikan daya tarik yang lebih meyakinkan.

Prinsip yang kedua adalah menumbuhkan motivasi pada anak. Kekuatan motivasi yang dikomunikasikan sangat penting bagi anak dalam bekerja maupun belajar. Keberhasilan komunikasi ini ditentukan oleh tindakan atau sikap sasaran yang tumbuh akibat dorongan dari dalam. Seorang anak dapat melakukan sesuatu dengan baik jika berpikir bahwa dia mampu untuk melakukannya. Hal ini akan berhasil tergantung pada pengertian bagaimana seorang anak menerima pandanganpandangan orang lain. Proses komunikasi secara keseluruhan menganjurkan perubahan yang terbaik menurut penilaian audiensnya. Dalam memberikan perubahan secara memyeluruh posisi orang dewasa harus dekat dengan anak, dan harus berempati dengan anak.

Prinsip yang ketiga adalah bersikap sejajar. Komunikasi yang efektif mensyaratkan adanya kesejajaran antara sumber dan sasaran, sumber tidak bersifat menggurui. Di sini tercipta suasana kebersamaan, sumber mencoba mendalami sasarannya, sasaran menganggap sumber sebagai teman, dan pesan dapat diterima akibat kedekatan yang terjadi (Depsos dan UNDP, 1997). Sikap kesejajaran ini ditunjukkan ketika orang dewasa tidak menganggap dirinya lebih tahu segalanya dari anak, sehingga cenderung memaksa anak untuk mengikuti kemauannya. Ketika ia menempatkan diri sebagai seorang teman bercerita, dan dia 
berusaha mendalami anak, maka sang anak akan merasa dekat, sehingga pesan yang disampaikan akan dilaksanakan oleh anak sebagai dorongan yang muncul dari dalam.

Prinsip keempat adalah memperbanyak diskusi. Komunikasi banyak melibatkan sasaran untuk menyampaikan pendapatnya dalam proses komunikasi. Orang dewasa dan anak ada dalam sebuah proses interaksi simbolik yang melingkar (Applbaum dan Anatol,1974: 203). Sangat mungkin, dalam komunikasi, pesan yang diterima merupakan hal yang sebenamya sudah diketahui oleh sasaran, sumber hanya memberikan penegasan atau penjelasan lebih kuat terhadap apa yang sudah dipahami sasaran (Depsos dan UNDP, 1997). Suasana diskusi dalam konteks anakanak akan lebih berupa kegiatan mengobrol atau bercerita bersama, lebih memungkinkan proses transfer pengalaman sesama anak. Dan anak akan lebih mudah memahami dan mendalami pesan ini, karena pesan ini bukan sesuatu yang asing bagi mereka.

Prinsip yang kelima adalah kebebasan berkreasi. Usia anak-anak adalah usia dimana harus dikembangkan daya kreasinya. Memberikan kebebasan berkreasi menjadi salah satu prinsip komunikasi yang penting untuk memaksimalkan perkembangan anak. Komunikasi bertujuan untuk menghasilkan sikap dan perilaku yang berubah. Sumber akan lebih berhasil jika dia membiarkan anak untuk menggambarkan dengan idenya masing-masing. Membiarkan anak untuk membuat kesimpulan sendiri akan sukses bila pesan yang disampaikan lebih kompleks. (Karlins dan Abelson, 1999: 99).

Prinsip keenam adalah menghargai perbedaan individu. Perbedaan individu mengindikasikan bahwa tidak ada dua anak yang merespon dengan cara yang sama dalam usaha pengaruh yang identik. Daya tarik yang sama diterima oleh audiens yang berbeda terjadi karena karakteristik kepribadian mereka yang berbeda. Kepribadian merupakan hal yang mudah mempengaruhi individu (Karlins dan Abelson, 1999: 110).

Prinsip ketujuh adalah mengarahkan secara halus. Usia anak-anak adalah usia dengan kondisi emosi yang belum matang sehingga ketika melakukan komunikasi dengan anak, orang dewasa harus menggunakan cara yang sesuai dengan kondisi anak sehingga akan lebih mudah diterima. Mengarahkan secara halus penting dilakukan oleh orang dewasa ketika berkomunikasi dengan anak. Cara-cara kasar cenderung membuat sasaran menjalankan keinginan sumber karena rasa takut, bukan atas kesadaran sendiri. Mengarahkan secara halus akan menghindarkan anak dari rasa takut dan keterpaksaan ketika anak melakukan sesuatu yang sebenarnya merupakan perintah dari orang dewasa atau atasannya. Suatu cara-cara halus yang menyentuh emosi dan afeksi anak akan membuat anak merasa memiliki dan menyenangi tindakan yang harus dilakukannya.

Prinsip kedelapan adalah pendampingan. Pendampingan membuat anak merasa tenang karena ada orang dewasa di sampingnya. Salah satu tujuan dari komunikasi adalah perubahan sikap dari sasaran, sehingga sumber perlu terus bertanggungjawab, mengawal atau mendampingi sasaran hingga pesannya sampai (Depsos dan UNDP, 1997). Komunikasi tidak akan efektif jika atasan (orang dewasa) hanya memberikan instruksi, dan kemudian membiarkan anak memahami pesan tersebut tanpa arahan. Ketika anak tengah menjalankan apa yang diinginkan sumber, maka pendampingan akan membuat anak merasa aman karena ia merasa ada yang siap memberi pertolongan jika ia membutuhkan.

Prinsip kesembilan adalah menciptakan suasana informal. Penciptaan suasana informal akan membuat perbedaan-perbedaan menjadi sesuatu yang mudah dimaklumi dan tidak menghambat komunikasi. Sumber berusaha menciptakan iklim yang informal dan santai dalam belajar maupun bekerja, dimana anak bebas mengekspresikan pendapat mereka. Persepsi ini dipengaruhi oleh nilai-nilai yang digunakan dalam komunikasi tersebut. J ika evaluasinya positif anak akan menerima ide yang disampaikan oleh sumber. J ika ternyata evaluasi yang kita berikan cenderung negative, kita harus memberikan motivasi pada anak misalnya dengan memberikan dorongan dan bimbingan secara terus menerus. Terkadang kalau diperlukan kita dapat juga memberikan penghargaan (reward).

Prinsip kesepuluh adalah mendengarkan keluh kesah. Komunikasi mengakomodasi hal-hal yang di luar konteks komunikasi namun berpengaruh pada kondisi emosional sasaran. Keluh kesah sasaran perlu menjadi pertimbangan, keluh kesah ini bisa menjadi penghambat ketika sasaran hendak menjalankan apa yang dimaui sumber. (Depsos dan UNDP,1997). Orang dewasa harus sabar dalam melayani keluh kesah anak.

\section{Simpulan dan Saran}

Berdasarkan konstruksi realitas sosial dilapangan masih banyak kita dapati pekerja anak, terutama pada industri-industri kecil. Rata-rata terdapat dua sampai lima pekerja anak pada sebuah industri kecil. Hampir keseluruhan dari mereka berasal dari kondisi ekonomi bawah. Berbagai dampak muncul dalam perkembangan pekerja anak ini baik dampak kesehatan, dampak psikologis dan keselamatan kerja.

Komunikasi pekerja anak dengan atasan meliputi pembicaraan hal-hal teknis yang berkaitan 
IKE JUNITA TRIWARDHANI, DKK. Pengelolaan Komunikasi Pekerja Anak di Industri Kecil Boneka Kain Kopo Bdg

langsung dengan pembagian pekerjaan, cara melakukan pekerjaan, pemberian motivasi untuk terus bekerja dan melaksanakan pekerjaan dengan baik. Komunikasi pekerja anak dengan pekerja dewasa meliputi pembicaraan yang berkaitan dengan bimbingan dalam melaksanakan pekerjaan, motivasi dalam melakukan pekerjaan, percakapan ringan disela-sela waktu bekerja dengan berbagai tema yang sering tidak cocok untuk anak-anak. Komunikasi Pekerja Anak dengan Sesama Pekerja Anak meliputi permasalahan di luar teknis pekerjaan. Mereka saling memotivasi untuk terus bekerja karena kondisi mereka yang rata-rata sama.

Dari komunikasi yang berkaitan dengan pekerja anak ada 10 prinsip komunikasi yang perlu dikembangkan yaitu meningkatkan kredibilitas, menumbuhkan motivasi pada anak, bersikap sejajar, memperbanyak diskusi, kebebasan berkreasi, menghargai perbedaan individu, mengarahkan secara halus, pendampingan, menciptakan suasana informal dan mendengarkan keluh kesah.

\section{Daftar Pustaka}

Applbaum, Ronald L. and Anatol, Karl W.E. (1974).
Strategies For Communication. Columbus, Ohio: Charles E. Merrill Publishing Company $\&$ A Beil \& Howell Company.

Boroualogo, I. S. (2008). Sistem Nilai Anak Usia 5 Sampai 10 tahun yang bekerja di desa Cisolok Sukabumi. Mimbar Jurnal Sosial dan Pembangunan Vol XXIV, No 2: P2U LPPM Unisba.

Gunawan, S. (2005). Kondisi Keluarga Fakir Miskin. Jurnal Puslitbang: Kemiskinan dan Keberfungsian Sosial

Hurlock, E. (1999). Perkembangan Anak. Jilid 1 \& 2. Alih Bahasa: dr. Med. Meitasari Tjandrasa. J akarta: Erlangga.

Karlins, M. and Abelson, H.I. (1999). Persuasion: how Opinions and Attitudes are Changed. New York: Springer Publishing Company

Larson, C. U. (1996). Persuasion: Reception and Responsibility.

Roekomy. (1992). Dasar-dasar Persuasif. Bandung: Citra Aditya Bakti.

Pedoman Penyelesaian Masalah Anak Jalanan. (1997). Jakarta: Departemen Sosial dan UNDP. 